\title{
Employee Performance as Function of Performance Management System: An Empirical Study Information Technology Enabled Services Companies around Hyderabad
}

\author{
Mruthyanjaya Rao Mangipudi*1, KDV Prasad*1 and Rajesh Vaidya ${ }^{2}$
}

\begin{abstract}
In this manuscript, we report the results of an empirical study carried out as to how performance management system in Information Technology Enabled Service Companies around Hyderabad is an integral function of HRM. A survey was conducted on the employees of IT Enabled Services companies around Hyderabad using a sample of 924 employees, consisting of 545 men and 379 women employees. The influence of performance management system was measured against the a) Factors responsible for improved employee performance and b) Factors that impact performance management system. Using a structured survey instrument a five-point Likert-type scale, 13 factors of dependent variable performance management system have been measured against the two independent variables. 9 factors were found responsible for improved performance and 5 factors found to be having impact on the performance management while applying multiple regression analysis. Reliability and internal consistency were measured using reliability statistic Cronbach Alpha which are $0.84,0.76$ and 0.73 respectively for performance management system, factors responsible for improvement performance management and factors that impact performance management system. The results reveal that both the independent variables significantly influence the performance management system and there were statistically significant gender differences observed in the sample. However, there were no significant differences in different age groups of the employees.
\end{abstract}

Index Terms-Cronbach Alpha, performance management system, Impact of PMS, Gender, IT Enabled companies

$\begin{array}{ccc} & \text { INTRODUCTION } & \\ \text { Performance } & \text { Management System (PMS) is a }\end{array}$ methodological and continuous approach to evaluate the performance of employees, teams, departments and aligning the objectives and goals of an organization as a whole with the individual goals of employees in any organization. The PMS enables the organization to see whether the there is any deviation in the performance of employees which affects the organization's mission, vision and goals. The PMS is basis in an organization for it to identify the current and the future competency gaps. PMS also helpful in conflict management, identifying training needs, mentoring employees and for optimizing the use of human resources and resource pools (Prasad et al., 2019). PMS has gained importance in recent times as an important subject of discussion with several organizations making considerable modifications in dealing with the management of performance. It is well noted that the

${ }^{1}$ Mruthyanjaya Rao Mangipudi and KDV Prasad with Department of Management Studies, RTM Nagpur University, Nagpur, Maharashtra, India(e-mail: raomangipudi@gmail.com; prasadkanaka2003@yahoo.co.in; - whilst performance management systems are efficient instigating some values, promote creativity, yet the effect of the performance management system is not of much concern to some of the organizations. The employees are the major stakeholders of any business and the organizations always plan to ensure that the approaches related to performance systems are concentrated towards growth and benefits of the employees as well (PWC 2016). Gungor (2011) opined that organizations concentrating on progress will motivate and enhance the performance in human resource operations for improved productivity. PMS is an approach for making sure employees will contribute to accomplish the goals and objectives of the organization. Developing and planning performance, managing and review, feedback and reward employee performance are some of the phases that involved in the performance management systems (Ying, 2012).

The organizations performance is based on overall performance of employees and the accomplishment of a business will rely on its capability to determine precisely the performance of companies' employees and employ it independently to optimize them as imperative resource (Biswajeet 2009). Performance management is obviously blessing for the employees in order to gain competitive advantage (Toppo and Prusty 2012). Any organization's longstanding success or failure is largely depending on the performance management systems. If the employees are not pleased with the performance management system they are more liable to be reluctant and under participated as they do not find any worth of process. The incompetent employee performance will reduce the organizations performance. The PMS deals with an accomplished and proficient management system for organizations to evaluate performance outcome of organizations and workforce (Babu and Suhasini 2017). Furthermore, performance is considered as personnel activity or performance that has been assessed as to its suitability or rightness in a managerial context (Paile, 2012). An effective performance management system allows the organization to comprehend exactly how far its employees are performing in current scenario (Mustafa, 2013). Performance Management Systems are employed mostly in dealing with human resource management and they play an important role in managerial strategy. In addition, organizations create performance management system to encourage and maintain their primary resources, their employees (Matlala. 2011)

${ }^{2}$ Prof. Rajesh Vaidya is with Department Of Management Technology, Shri Ramdeobaba College of Engineering \& Management, Ramdeo Tekdi, Gittikhadan, Nagpur-440013 (e-mail: vaidyarw@rknec.edu) 
The PMS procedure involves activities like goal setting prioritizing the tasks, performance monitoring, coaching, communicating, performance review, offering feedback and motivating as and when required. (Gupta and Kumar 2012). According to Gudla and Veni (2012) performance management system has become a significant tool that is used for the overall development of organization as well for the employees. Mura reported that in some organizations PMS is designed in accordance with the need of the company. The ITES companies like Tech Mahindra, Wipro, Accenture located in Hyderabad are implementing effective Performance Management Systems for benchmarking, setting of standards to make comparisons (Jahanshashi et al 2011). Wu, Hahajan and Balasubramanian (200) reported that the managers of the ITES companies were found to be using performance management practice to compare the internal change efforts. The approaches like 360-degree feedback, were used in the performance appraisals. According to Agyare et al. (2016) balanced scoreboard was extensively used for the purpose of strategic planning to monitor the organization's performance against the strategic goals. According to Youndt, Snell, Dean Jr and Lepak (1996) the managers are found to be practising performance management systems into the working of the ITES organizations and that the organization could assess the reason or shortcomings in the performance of the employees. Introduction of performance management system into the working of the ITES organizations encouraged the working staff (Gunasekaran et. al. 2001). Balasubramanian (2003) reported that used the performance assessment tools the ITES companies were able to assess the performance of an employee and accredit them in a well-defined matter to increase the motivation and inspiration to create a positive attitude in the working environment. A survey conducted by Labor Statistics reported that in the ITES companies the practice of the performance management system used to assess the employee performance increased the productivity considerably. According to Zhou, Wei, Chen and Li (2010) large ITES companies like Amazon, Deloitte and Google Operating in Hyderabad have bought significant changes into the working conditions of the organizations and replaced the annual review reports with the performance management systems which are most effective. Kumari (2017) observed that the major tools for PMS are similar in the ITES industry and that this industry undergoes a trend of linking performance with promotion and rewards. Kumari (2017) reported that HR focus areas like career development, succession planning, learning and development are the essential components of PMS. Motivation is also a factor and influence the performance appraisal according to Sanyal and Biswas (2014). Attrition is a major problem in ITES enterprises, and HRM practices like succession planning, training development, and career development an be integrated in HR focus areas which can help to mitigate the attrition. Makhubela et. al. (2016) studied quantifiable factors that influence the effectiveness of PMS and observed lack of transparency in the performance measures impedes the PMS effectiveness.
Based on the research reviews the authors could not find a single study on the effect of performance management system with employee competencies using regression analysis. To fill this research gap the authors made a sincere attempt with this empirical survey to study the effect of employee competencies on PMS.

\section{OBJECTIVES AND HYPOTHESES}

The authors found very limited research even after a vigorous search to predict the effect of performance management systems using the factors that effect like factors responsible for improved performance management system, factors that impact the performance management systems. Even no related research documents and literature was found, therefore the authors carried out this empirical study on the employees of IT Enabled Services companies around Hyderabad.

The following hypotheses are formed for this empirical study

H01: Employee performance improvement factors do not influence the performance management system of IT Enabled Services companies

$\mathrm{H}_{11}$ : Employee performance improvement factors influence performance management system of IT Enabled Services companies

$\mathrm{H}_{02}$ : Employee performance does not impact the performance management system of IT Enabled Services companies

$\mathrm{H}_{12}$ : Employee performance impacts the performance management system of IT Enabled Services companies

Conceptual framework: The proposed framework was adopted based on the performance management system framework provided adopted by Prasad et al. (2019) and the framework follow in this study is provided in Figure 1.

\begin{tabular}{lll}
\hline \multicolumn{3}{c}{ TABLE I: DEMOGRAPHIC CHARACTETISTICS } \\
\multicolumn{3}{c}{ OF SURVEY SAMPLE } \\
\hline Age Group & Number & Percent \\
\hline $20-26$ & 149 & 16.1 \\
$27-30$ & 176 & 19 \\
$31-40$ & 156 & 16.9 \\
$41-50$ & 151 & 16.3 \\
$51-60$ & 156 & 16.9 \\
60 and above & 136 & 14.7 \\
Total & 924 & 100 \\
\hline Men $=\mathrm{n}(545)=59.0 \% ;$ \\
Women n(379) $41.0 \%$ Total $=924$ \\
Source: Primary Data \\
\hline
\end{tabular}




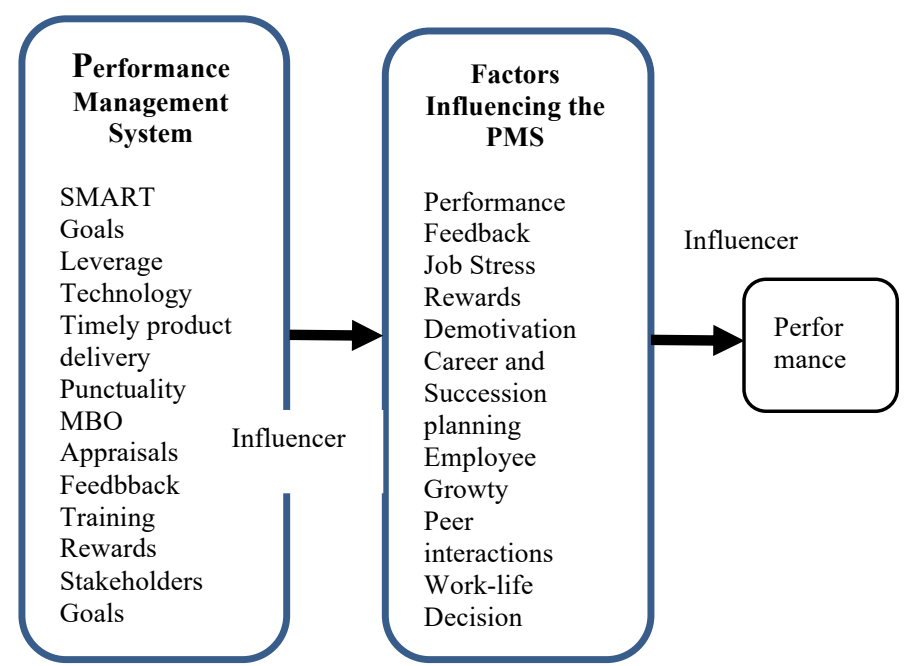

Fig. 1. Conceptual framework: Factors influencing the perforamnce vs performance management system

\section{RESEARCH METHODOLOGY}

\section{A. Sample size}

From the population a sample size of $(n=924)$ was used for the study selected by a simple random sampling method where each member of the subset has equal probability of being chosen and the samples includes 549 men and 375 women.

\section{B. Primary data gathering}

The research instrument used for this empirical study was a structured survey questionnaire using 2 scales a) For measuring dependent variables with 13 factors, a Likert-type 5 -point scale was used in the study where $(5=$ Extremely Relevant; Very relevant $=4$; Slightly relevant $=3$; Moderately relevant $=2$; and Not at all relevant $=1$ ) and b) For independent variables with 9 factors, (responsible for improved employee performance and impact of performance management system on employee performance) again a Likert-type scale was used in the study where Strongly agree $=5$; Agree $=4$; Neutral $=3$; Disagree $=2$; Strongly disagree $=1$. The survey also presented 5 significant factors that indicated the impact of performance management system on employee performance. The demographic characteristics of the study were presented in Table I and the factors for the dependent and independent variables presented in Table II. III.

\begin{tabular}{lll}
\hline \multicolumn{2}{l}{ TABLE II: DESCRIPTION OF THE FACTORS IN EMPIRICAL } \\
& & STUDY \\
\hline S1 & Factors & Items \\
No & & \\
\hline 1 & Performance & 13: Efficient utilization of \\
& Management & available resources, \\
& System & $\begin{array}{l}\text { Maintenance of good quality } \\
\text { standa4rds, Maintenance of } \\
\end{array}$ \\
& & safety standards, Clearly \\
& intimating employees with
\end{tabular}

work deadlines, On time product delivery, Punctuality maintained by staff members, Awareness among employees about their work quality impact, Regular training of employees, Regular performance assessments of employees, Recognition and reward for good performance, Consideration of employees job satisfaction; Performing corporate social liabilities; Employee capability to differentiate among personal and organizational objectives

2 Factors 9: Performance feedback; responsible Level of stress; Performance for improved standards; Clarity about goal; employee Performance-based rewards; performance Demotivation of employees due to poor performance recognition; Lack of career planning; Constant career growth options; Regular workrelated interaction with supervisor

3 Factors 5: Enhanced work life, impact Improved efficiency in getting performance work done, Improvement in due to work-related key performance competencies; Encouraged management employees to participate in the system decision making process; Encouraged employees in exercising their rights

\section{Data analysis}

For our empirical investigation, we have applied statistical methods to analyze the data for drawing inferences. The data summarized using the descriptive analysis. Hypotheses were formulated using inferential statistics.Dispersion methods were used to measure the central tendency like mean, standard deviation, and variance using statistical package for social sciences ver 26 .

\section{Reliability methods}

To test the internal consistencies and reliability of the survey instrument the reliability statistics Cronbach alpha, split-half correlation, Spearman Brown prophecy were used to measure and to indicate all the items in the instrument related to the survey instrument (Gay et al., 2006). The research instrument was tested with 150 employees data using SPSS ver 26 and overall Cronbach alpha was estimated as 0.70. After completion of the survey of all the employees $(n=924)$ Cronbach alpha value was measured which indicated 0.84 which was a considerable improvement. The $\mathrm{C}$-alpha values for men ranged from 0.65 to 0.80 for men and for women 0.63 to 0.84 . The reliability statistics details were presented in Table III. The measured Cronbach alpha values are $>0.6$ suggesting a strong internal consistency. The second 
reliability measure Spearman Brown Split-Half correlation and Spear Brown Prophecy were computed to assure the overall survey instrument reliability and the values indicate strong reliabilities.

\begin{tabular}{|c|c|c|c|}
\hline \multicolumn{4}{|c|}{$\begin{array}{l}\text { TABLE III: RELIABILITY STATISTICS OF THE } \\
\text { SURVEY INSTRUMENT } \\
\text { (A: C-alpha, B: Split-half (odd even) } \\
\text { correlation, C: Spearman Brown } \\
\text { Prophecy) }\end{array}$} \\
\hline \multicolumn{4}{|c|}{ Factor } \\
\hline Men & A & B & $\mathrm{C}$ \\
\hline $\begin{array}{l}\text { Performance } \\
\text { Management } \\
\text { System }\end{array}$ & 0.84 & 0.76 & 0.88 \\
\hline
\end{tabular}

\begin{tabular}{|c|c|c|c|}
\hline $\begin{array}{l}\text { Factors } \\
\text { responsible } \\
\text { for improved } \\
\text { employee } \\
\text { performance }\end{array}$ & 0.74 & 0.71 & 0.79 \\
\hline $\begin{array}{l}\text { Factors } \\
\text { impact } \\
\text { performance } \\
\text { due to } \\
\text { performance } \\
\text { management } \\
\text { system }\end{array}$ & & & \\
\hline Women & & & \\
\hline $\begin{array}{l}\text { Performance } \\
\text { Management } \\
\text { System }\end{array}$ & 0.84 & 0.76 & 0.80 \\
\hline $\begin{array}{l}\text { Factors } \\
\text { responsible } \\
\text { for improved } \\
\text { employee } \\
\text { performance }\end{array}$ & 0.72 & 0.63 & 0.76 \\
\hline $\begin{array}{l}\text { Factors } \\
\text { impact } \\
\text { performance } \\
\text { due to } \\
\text { performance } \\
\text { management } \\
\text { system }\end{array}$ & 0.74 & 0.66 & 0.75 \\
\hline
\end{tabular}

E. Relationship among the study variables:

A Pearson's bivariate product moment correlation was run to assess the relationship between the performance management system and personal, job-related, knowledge level, and communication and interpersonal competencies for IT Enabled Service companies $(\mathrm{N}=924)$. Preliminary analysis showed the relationship with both the variables normally distributed, as assessed by Shapiro Wilk test ( $\mathrm{p}>0.05)$, and there were no outliners. There was a high positive correlation between performance management system and all the four employee competencies and is significant at 0.01 level (2- tailed, Table 4). And all four competencies are significant predictors of the performance management system.

\begin{tabular}{|c|c|c|c|}
\hline \multicolumn{4}{|c|}{$\begin{array}{l}\text { TABLE IV. BIVATIAE PRODUCT MOMENT } \\
\text { CORRELATION (N=924) }\end{array}$} \\
\hline & $\mathrm{A}$ & $\mathrm{B}$ & $\mathrm{C}$ \\
\hline A & 1 & $.769^{* *}$ & $.857^{* *}$ \\
\hline B & $.769^{* *}$ & 1 & $.783^{* *}$ \\
\hline $\mathrm{C}$ & $.857^{* *}$ & $.783^{* *}$ & 1 \\
\hline \multicolumn{4}{|c|}{$\begin{array}{l}\text { A: Performance Management System; B: } \\
\text { Factors responsible for improved } \\
\text { employee performance; C: Factors impact } \\
\text { on performance management system } \\
\text { **. Correlation is significant at the } 0.01 \\
\text { level (2-tailed). }\end{array}$} \\
\hline
\end{tabular}

\section{IV.MULTIPLE REGRESSION ANALYSIS}

The two independent variables factors responsible for improved employee performance, Factors impact on performance management system entered simultaneously for the analysis using the enter method.

\begin{tabular}{|c|c|c|c|}
\hline \multicolumn{4}{|c|}{ TABLE V: MODEL SUMMARY } \\
\hline Model & R Square & $\begin{array}{l}\text { Adjusted } \\
\text { R Square }\end{array}$ & $\begin{array}{l}\text { Std. Error of } \\
\text { the Estimate }\end{array}$ \\
\hline 1 & $.873 *$ & .761 & .32880 \\
\hline $\begin{array}{l}\text { a. Pre } \\
\text { improv } \\
\text { perform } \\
\text { b. Depe } \\
\text { system } \\
\text { Durbin }\end{array}$ & $\begin{array}{l}\text { ctors: (Constant), } \\
\text { employee performa } \\
\text { nce management sys } \\
\text { dent Variable: perfor } \\
\text { Vatson Value: } 1.735\end{array}$ & $\begin{array}{l}\text { Factors } r \\
\text { ance; } \mathrm{C}: \mathrm{Fa} \\
\text { tem } \\
\text { mance man }\end{array}$ & $\begin{array}{l}\text { sponsible for } \\
\text { tors impact on } \\
\text { gement }\end{array}$ \\
\hline
\end{tabular}

The multiple correlation coefficient, which is abbreviated to just $R$, is simply the Pearson correlation coefficient between the scores predicted by the regression model (i.e., the predicted scores) and the actual values of the dependent variable. In this model, $R$ is a measure of the strength of the linear association between these two variables and can give an indication as to the goodness of the model fit with a value that can range from 0 to 1 , with higher values indicating a stronger linear association. A value of $\mathbf{0 . 8 7 3}$, in this example, indicates a high level of association. However, that the multiple correlation coefficient, $R$, is not a common measure used to assess goodness of fit (Table V).

The $R^{2}$ is equal to $\mathbf{0 . 7 6 2}$ in from the table indicates that the addition of all our independent variables into a regression model explained $76.2 \%$ (i.e., $0.762 \times 100=76.2 \%$ ) of the variability of our dependent variable, Performance (compared to the mean model).

The $R^{2}$ is based on this study is considered a positively-biased estimate of the proportion of the variance of the dependent variable accounted for by the regression model (i.e., it is larger than it should be when generalizing to a larger population). However, it is still considered by some to be a good starting measure to understanding the results (Draper \& Smith, 1998). The adjusted $R^{2}$ which corrects for this positive 
bias in order to provide a value that would be expected in the population. The adjusted $R^{2}$ value at 0.705 is indicative of a high effect size according to Cohen's (1988) classification.

Statistical significance of the model: The significance value in ANOVA Table VI is .000 which actually means that $\mathrm{p}<.0005$, and $\mathrm{P}<.05$ is statistically significant result and an addition of all independent variables leads to a model that is statistically significant, and predict the dependent variable better than the mean model and statistically significantly better fit to the data than the mean model. The results are $\mathrm{F}(2$, 921) $=1541.004, \mathrm{P}<.0005$; where $\mathrm{F}$ indicated that $\mathrm{a}$ comparison with F-distribution (F-test) is made, 2 in $(2,923)$ is degrees of freedom, 923 in $(2,923)$ indicate the residual degree of freedom, 1451.004 is obtained value of the Fstatistic i.e. F-value and $\mathrm{P}<.0005$ is the probability of obtaining the observed F-value if the null hypothesis is true (Table VI).

\begin{tabular}{|c|c|c|c|c|c|}
\hline \multicolumn{6}{|c|}{ TABLE VI: ANOVA } \\
\hline Model & $\begin{array}{l}\text { Sum of } \\
\text { Squares }\end{array}$ & df & $\begin{array}{c}\text { Mean } \\
\text { Square }\end{array}$ & $\mathrm{F}$ & Sig. \\
\hline 1 Regression & 317.212 & 2 & 158.606 & 1451.004 & $.000^{\mathrm{b}}$ \\
\hline Residual & 100.672 & 921 & .109 & & \\
\hline Total & 417.884 & 923 & & & \\
\hline
\end{tabular}

a. Dependent Variable: performance management system b. Predictors: (Constant), Factors responsible for improved employee performance, Factors impact on performance management system and performance management system and performance management system

TABLE VII: REGRESSION COEFFICIENTS FOR FACTORS RESPONSIBLE FOR IMPROVED EMPLOYEE PERFORMANCE, FACTORS IMPACT PERFORAMNCE MANAGEMENT SYSTEM AND PERFORMANCE MANAGEMENT SYSTEM

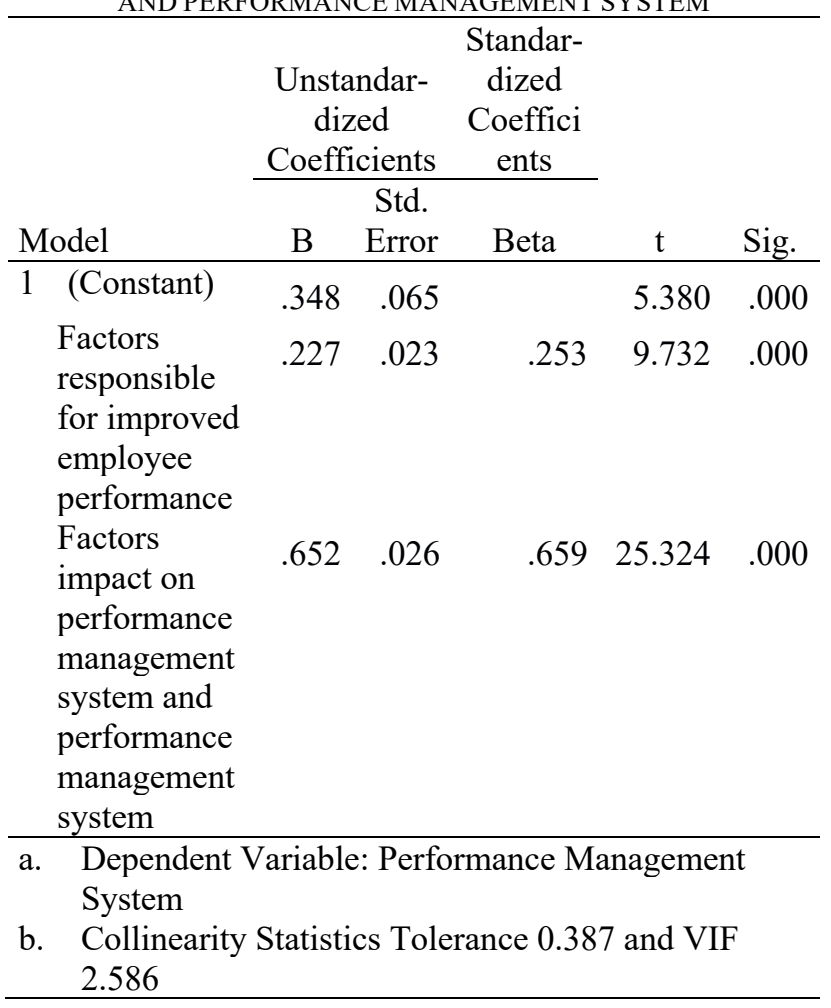

Interpreting the coefficients: The regression equation for the model can be expressed as:
Performance Management System = bo_(b1 x Factors responsible for improved employee performance, $)+(\mathrm{b} 2 \mathrm{x}$ Factors impact on performance management system and performance management system)

Performance Management System $=0.348+0.227$ (Factors responsible for improved employee performance) +0.652 (Factors impact on performance management system and performance management system)

For the independent variable Factors responsible for improved employee performance, for one unit change in this independent variable. 0.227 units of PMS is positively improved, keeping all other variables constant. If we consider standardized coefficients a beta value of 0.253 indicates that a change of one standard deviation in the independent variable Factors responsible for improved employee performance, results in a 0.253 standard deviations performance management system will be positively improved, keeping all other variables in the model constant. In a similar way if we consider for unit increase of Factors impact on performance management system and performance management system will increase 0.652 units of PMS positively improved. If we consider standardized coefficients of this variable a change in one standard deviation in independent variable Knowledge level competencies improves the PMS by 0.659 standard deviations, and so on (Table VII) indicating positive effect on performance management system from the independent variables.

Interpretation of the multiple regression analysis results: A multiple regression was run to predict effect on performance management system from Factors responsible for improved employee performance, and Factors impact on performance management system and performance management system $(\mathrm{n}=924)$. There was linearity as assessed by partial regression plots and a plot of studentized residuals against the predicted values. There was independence of residuals, as assessed by a Durbin-Watson statistic of 1.735. There was homoscedasticity, as assessed by visual inspection of a plot of studentized residuals versus unstandardized predicted values. There was no evidence of multicollinearity, as assessed by tolerance values greater than 0.1 . There were no studentized deleted residuals greater than \pm 3 standard deviations, no leverage values greater than 0.2 , and values for Cook's distance above 1 . The assumption of normality was met, as assessed by a Q-Q Plot. The multiple regression model statistically significantly The multiple regression model statistically significantly predicted PMS, F $(2,24)=$ 1451.004, $\mathrm{p}<.0005$, adj. $\mathrm{R}^{2}=0.761$. All the two added variables statistically significantly to the prediction, $\mathrm{p}<.05$. Regression coefficients and standard errors can be found in Table VII. This indicates to reject the null hypothesis and accept that There is a correlation between, Factors responsible for improved employee performance, Factors impact on performance management system and performance management system $(n=924)$. All the variables are predicting the PMS significantly.

Therefore, we reject the null hypothesis Ho1: Employee performance improvement factors does not influence the performance management system of IT Enabled Service companies and accept the alternate hypothesis $\mathbf{H}_{11}$ : 
Employee performance improvement factors influence performance management system of IT Enabled Service companies; and reject the null hypothesis $\mathbf{H}_{\mathbf{0 2}}$ : Employee performance does not impact the performance management system of IT Enabled Service companies and accept the alternate hypothesis $\mathbf{H}_{12}$ : Employee performance impacts the performance management system of IT Enabled Service companies and the results are in line with the studies carried out by Prasad et al (2016, 2017 and 2018; Messah and Kamencu, 2011).Magnolia Tilca et al (2018, Mamatha and Prasad (2017), and Elijah Ng'ang'a Njuguna and Bula Hannah Orwa (2015) who carried out the research using multiple regression analysis. The post hoc results indicate no significant influence of age group among the factors that are effecting the PMS.

\section{DISCUSSION}

The authors carried out this study as there are very limited research items available predicting the effect of Factors responsible for improved employee performance, and the impact of the performance management system on employee performance.. The presented results in line with the several performance management system studies carried out by various researchers using multiple regression analysis. The Omboi Bernard Messah and Shadrack M. Kamencu (2011) carried out a study using regression analysis to predict the ijmpact of Performance Management System on Employees in Kenya Tea Development Agency using a survey and our results were more or less similar to the study. Survey research to have some problems of reliability of the survey instrument and author has limited knowledge whether the respondents spent considerable time to read the question by question or just selected the answers arbitrarily. However, the authors were able to overcome this problem by applying the reliability statistics Cronbach alpha and Split-half statistic indicated that there is a strong reliability and internal consistency in the survey instrument. The authors also faced the problem of absence of related research publications and models. The model was developed with the limited available models and appropriate survey instrument was prepared and the empirical study was carried out. The survey instrument was published using google corms and hard copies were provided for the needed. To conclude that independent variables, Factors responsible for improved employee performance and Factors are significantly influencing the performance management system in IT Enabled Service companies.

\section{CONCLUSION}

The use of performance management system is must to bring out improvements in the employee performance and enhanced the performance functioning of organizations at high level. The PMS focus areas like individual development plans, training requirement of an employee, succession and career planning need to be integrated in PMS for organization development and performance improvement (Ramanuj, 2012). The design and implementation of the performance management system in any organization depend on its goals, vision, mission and business model. However, for implementation the employee positive behaviour is must. The author suggest the performance appraisal should be at least twice a year with relevant feedback. In yearly performance appraisal system the management need wait for a year and this is not advisable because volatile business operations and rapid technology development. The authors believe the presented approach can be used for similar type of studies in any organization to study the effect similar independent variable on performance management system. The organisations need to come our of 3600degree appraisal system that employed once a year because of volatile business environments and fast development of technologies. The individual organisations should develop a PMS mechanisms and related tools based on the organization business needs to avoid rating biases and effective implementation of PMS.

\section{REFERENCES}

Agyare, R., Yuhui, G., Mensah, L., Aidoo, Z., and Ansah, I. (2016). The impacts of performance appraisal on employees job satisfaction and organizational commitment: A case of microfinance institutions in Ghana. International Journal of Business and Management, 11(9), 281.

Babu, T.N., \& Suashini, N. (2017). Performance management - effective tool for talent management International Conference on Emerging Trends in Engineering, Technology, Science, and Management, 99581-585.

BISWAJEET, P. 2009. Human resource management. PHI Learning Private Limited.

Columbus: Merrill Greenwood.

Draper, N. R., \& Smith, H. (1998). Fitting a straight line by least squares. Applied regression analysis, 15-46.

Gay, L.R., Mills, G.E. \& Airasian, P. (2006). Educational Research: Competencies for Analysis and Applications.

Gudla, S, and Veni, V. (2012). The study of performance management system in IT Organisations. IOSR Journal of Business Management, 6(3):37-52

Gunasekaran, A., Patel, C., \& Tirtiroglu, E. (2001). Performance measures and metrics in a supply chain environment. International Journal of Operations and Production Management, 21(1/2), 71-87.

Gungor, P. (2011). The relationship between reward management system and performance. Procedia Social and Behavioural Sciences 1510-1520

Kumari, N. (2017). A comparative study of performance management system in IT/ITES Industry. London Journal Press 17(1), 1-10

Kumari, N. (2017). A study of performance management system in IBM. Business and Management Reserch Journal 7(2), 19-24

Mamatha, Ch., \& Prasad, K.D.V. (2017). Employee Performance A Function of Social Support And Coping: A Case Study with Reference to Agricultural Research Sector Employees Using Multinomial Logistic Regression. IOSR Journal of Business and Management 19 (7), 12-21.

Matalala, M.M. (2011). Performance management hurdles in a Public Health Sector Organization in Zimbabwe. European Scientific Journal, 11(32)244-261

Makhubela, M., Biotha, P.A., \& Swanepoel, S. (2016). Employees' perceptions of the effectiveness and fairness of performance management in South African public sector institution. SA Journal of Human 
Resource

Management/SA

TydikrifvirMenlikehulpbronbestuur 14(1), 728.

Messah, O.B., \& Kamencu, S.M.(2011) Effect of Performance Appraisal Systems on Employees in Kenya Tea Development Agency: A Survey of Selected Tea Factories in Meru County-Kenya. Research Journal of Finance and Accounting 2(3), 16-35

Mruthyanjaya Rao Mangipudi., (2018). Performance Management Systems in IT Enabled Services (ITES) and its impact on improvement in employee performance with reference to mobile commerce companies operating in and around Hyderabad. ( A doctoral thesis submitted to the RTM Nagpur University, Nagpur during October 2018)

Mustafa, M.S., (2013). Key factors in performance management: Employee point of view. Dissertation, Hamk University of Applied Sciences.

Njuguna, E.N., and Orwa, B.H. 2015. Antecedents of Performance Appraisal and Organizational Performance in Water and Sanitation Companies in Kenya:A Case of Murang'a Water and Sanitation Company limited. International Journal of Business and Economics Research.4(5): 250-263, doi: 10.11648/j.ijber.20150405.14

Paile, N.J., (2014). Employee Performance Appraisal Satisfaction: The Case Evidence from Bruner's Civil Service. PhD. The University of Manchester

Prasad K.D.V., \& Rajesh Vaidya. (2018). Association among occupational stress factors and performance at workplace agricultural research sector employees at Hyderabad, India. Pacific Business Review International 10(7):27-36

Prasad, K. D.V., \& Vaidya, R. (2018). Causes and Effect of Occupational Stress and Coping on Performance with Special Reference to Length of Service: An Empirical Study Using Multinomial Logistic Regression Approach. Psychology, 9, 2457-2470 -2470.

Prasad, K.D.V., \& Vaidya, R. (2018). Causes and effect of occupational stress and coping on performance and psychological well-being among the Agricultural Research Sector: An Empirical Study using Multinomial Logistic Regression Approach. Helix Journal - The Scientific Explorer. 8(6)4114-4119. DOI 10.29042/2018-4114-4119.

PWC. (2006). Performance management in India A change beckons. PWC Publications.

Ramanuj, N.K. (2012). Measuring the total performance of Reliance Communication-through balance scorecard (Doctoral dissertation, Saurashtra University), http://etheses.saurashtrauniversity.eduy/760/

Sanyal, M.K., \& Biswas, S,B. (2014). Employee motivation from performance appraisal implications: Test of a theory industry in West Bengal(India). Procedia Economics and Finance 11, 182-196.

Tilca, M., Mare, E., \& Apatean, A. (2018). A model to measure the performance of human resources in organizations. Studia Universitatis "Vasile Goldis" Arad. Economics Series 28(1):57 - 73

Toppo, L., and Prusty, T. (2012). From performance appraisal to performance management. Journal of Business and Management 3(5): 16.

Ying, Z.Y., (2012). The impact of performance management system on employee performance. Retrieved on $2^{\text {nd }}$
December 2017. http://essay.utwente.nl/62260/1/Daisymaster thesis.pdf

Youndt, M.A., Snell, S.A., Dean Jr, J.W., \& Leopak, D.P. (1996). Human resource management, manufacturing strategy, and firm performance. Academy of Management Journal. 39(4), 836-866

Zhou, J., Wei, J., Chen, L., \& Li, Z. (2010). SaaS-modelbased approach for mobile government security. International Journal of Mobile Communications, 8(6), 654-666. 